\author{
Review Article
}

\title{
IMPORTANCE OF TRIVIDH KUKSHIYA MATRAVAT AAHARA IN RELATION TO DIGESTION OF THE FOOD
}

\section{Manjiri Palnitakar Bhende1, Prachi Dwarkaprasad Walde ${ }^{2 *}$}

${ }^{1}$ Assistant Professor, ${ }^{* 2}$ PG Scholar, Department of Swasthavritta and Yoga, R. A. Podar Medical (Ayu) College,

Worli, Mumbai, India.

\begin{tabular}{l} 
Article info \\
Article History: \\
Received: 01-09-2021 \\
Revised : 15-09-2021 \\
Accepted: 28-09-2021 \\
Published: $16-10-2021$ \\
\hline KEYWORDS: \\
Trividh kukshiya, \\
Matravat Aahara, \\
Digestion of food.
\end{tabular}

ABSTRACT
According to Ayurveda food is one of the significant factors for health as well as source for
diseases i.e., wholesome food is responsible for pleasure and unwholesome food is
responsible for unhappiness. Alongside the quality of food, the quantity of food is also a lot
of significant that how it is taken, on the grounds that food taken in ill-advised manner can
prompt various diseases. Digestion of food is considered as one of the most important
physiologic processes in our body to be of prime significance in conserving health. A
nutritious eating regimen won't have the most extreme effect in promoting health unless
the digestive capacity is optimal. Balanced Agni (digestive fire) is basic for appropriate
digestion of food, for this reason the idea of Matravat ahara ought to be considered as
portrayed in Trividhkukshiya viman adhyay. For proper digestion of food, it should be
consumed in appropriate quantity as described in Trividh kukshiya adhyaya, where it is
specifying that, stomach capacity is divided into 3 parts: One part of it is filled up with solid
food, the second part with liquids and the third part is left for Vata, Pitta and Kapha. Thus,
the good quality food taken in appropriate amount will nourish the tissue elements of the
body along with mind and senses only when it is properly digested. This article aimed to
signify importance of Trividh kukshiya matravata aahara for proper digestion.

\section{INTRODUCTION}

In Ayurveda, optimal digestion is considered to be of prime significance in conserving health. A nutritious eating regimen won't have the most extreme effect in promoting health unless the digestive capacity is optimal. Balanced Agni (digestive fire) is basic for appropriate digestion of food, for this reason the idea of Matravat ahara ought to be considered as portrayed in Trividhkukshiya viman adhyay.

Diets and drinks whose colour, smell, taste and touch are pleasing to the senses and conducive to the health, if taken in accordance with the rules described in Aharvidhivisheshayatan and Trividhkukshiya viman adhyay, in fact represent the very life of living beings. The effect of the use of such diets and drinks can be perceived directly.

\section{Access this article online}

\begin{tabular}{|c|c|}
\hline \multicolumn{2}{|l|}{ Quick Response Code } \\
\hline & https://doi.org/10.47070/ijapr.v9i9.2029 \\
\hline & $\begin{array}{l}\text { Published by Mahadev Publications } \\
\text { (Regd.) publication licensed under a } \\
\text { Creative Commons } \\
\text { NonCommercial-ShareAlike } \\
\text { International (CC BY-NC-SA 4.0) }\end{array}$ \\
\hline
\end{tabular}

Whenever consumed by rules, they give fuel to the fire of digestion; they endorse mental as well as physical strength, strength of tissue elements and complexion and they are satisfying to the senses [1].

Digestion of food is considered as one of the most important physiologic processes in our body. A few components assume a vital part in proper digestion and absorption such as mixing action of stomach and gastrointestinal motility, enzyme secretion and activity, proper mucosal function, favorable blood supply and normal microbiome[2]. For this purpose, to be achieved, the stomach capacity is divided into 3 parts: one is solid food, second one is liquid and third one for Vata, Pitta and Kapha. [3].

Consequently, any defect in these factors can affect the absorption of nutrients which may result in development of a wide range of disorders such as neurologic dysfunctions, skin diseases, respiratory diseases and rheumatic disorders ${ }^{[4]}$.

\section{MATERIALS}

The data from various articles, texts along with Brihatrayee has been collected, compiled and analyzed 
for the discussion and attempt has been made to draw some conclusions.

\section{DISCUSSION}

The digestion of food starts from the process of ingestion to the process of defecation. Throughout this process many physiological activities are carried out by our digestive system. The Ahara parinamkar bhava as depicted in Charaka Samhita, are the elements which are liable for digestion. These are Ushma, Vayu, Kleda, Sneha, Kaal and Samayog. The physiological exercises of stomach related framework are influenced by these 6 components which, when work appropriately are responsible for Parinaman or Paripak for example digestion of food and for these components to work suitably Matravat arahar is should have been consumed.

1. Ushma- Means Agni, Trayodasha agni i.e., Pachak pitta, Panch mahabhutagni and Sapta dhatvagni. Secretion of digestive enzymes and other substances liquefies, adjusts the $\mathrm{pH}$ and chemically breaks down the Food.

2. Vayu- Portrayal about Vayu given in texts gives clear thought regarding propelling movement of muscles of stomach which assists the food to be more in touch with gastric juice.

3. Kleda can be correlated with water intake during meal. According to modern researchers, water admission during meal assists with releasing the food appropriately and furthermore stimulates gastric discharges.

4. Sneha i.e., unctuousness is necessary for proper digestion. According to modern researches, hard food can't get digested appropriately; it required Sneha for proper digestion.

5. Kala can be related with Jirne (admission of food after digestion of previous food), Nati-vilambita (not exceptionally dormant) and Natidruta (not extremely fast) Bhojana. Because of admission of food before assimilation of past food and moderate admission of food, past food gets stirred up with the product of food taken afterward, which ultimately cause indigestion. About Nati-druta bhojana, legitimate chewing of food would guarantee appropriate blending and extricating of food in the buccal cavity. Nowadays people eat very urgently where they do not allow the food to get chewed properly. Proper blending of saliva isn't guaranteed which may likewise prompt hard food entering the stomach which doesn't get easily digested.

6. Samayog- Diet should be taken according to rules described in Aaharvidhivisheshayatana for proper digestion ${ }^{[5]}$.

In any event, when no food is available in the stomach, a little amount of liquid is released from the Pavlov's little stomach. The rate of flow of this fluid is very slow; it is in general 1-1.5 cc. each hour from a little stomach of the moderate size. This secretion is a thick, viscid mucous fluid, and contains mucin flakes in such abundance at times that the whole will make a solid mass. The empty stomach secrets a juice contains enzymes like pepsin pepsinogen, rennet, lipase, nuclease, amylase and maltase which are accountable in generating hunger[6]. There are two essential hormones associated with hunger signals: ghrelin and leptin. At the point when you haven't eaten for quite a while, the stomach produces ghrelin, which expands hunger, gastric motility and gastric acid secretion. Ghrelin levels are highest right before meals, when blood sugar is low and stomach is empty. On the other hand, when you've eaten enough, fat cells secrete leptin, which interacts with the brain to indicate that you have enough calories in storage, and it is therefore time to inhibit hunger signals[7]. Leptin is a hormone secreted by adipocytes and leptin has major role in the body weight regulation by maintaining a balance between food intake and expenditure of energy. Leptin is neurotransmitter expressed in brain. This neurotransmitter signals to the brain primarily in the hypothalamus that when a person stops to eat for keeping up with Body Mass Index[8]. This shows that Aahara taken according to Trivida kukshi is helpful in regulating leptin hormone which is important in maintaining BMI, thus prevent diseases like indigestion, obesity, hyperlipidemia and heart diseases. Our Acharyas must have an insight of this mechanism of hormonal regulation that's why they explain the phenomenon of Trividh kukshiya.

The process of gastric secretion can be can be isolated into three stages cephalic, gastric, and gastrointestinal stage. The stomach assumes a basic part in the beginning phases of food absorption. Asides from pressing and stirring the food bolus, it additionally secretes a combination of mixtures, all things considered known as "gastric juice." The gastric mucosa secretes 1.2 to 1.5 liters of gastric juice per day. Gastric juice includes water, mucus, hydrochloric acid, pepsin, and intrinsic factor. Of these five parts, pepsin is the primary enzyme associated with protein assimilation. It separates proteins into more modest peptides and amino acids that can be easily absorbed in the small intestine. Explicit cells inside the gastric covering, known as chief cells, discharge pepsin in an inert structure, or zymogen structure, called pepsinogen. Thusly, the stomach forestalls the autodigestion of defensive proteins in the covering of the gastrointestinal system. Since chief cells discharge pepsin as a zymogen, initiation by an acidic climate is significant. Hydrochloric acid $(\mathrm{HCl})$, another component of the gastric juice, plays a crucial role in creating the $\mathrm{pH}$ required for pepsin activity. Parietal cells produce $\mathrm{HCl}$ by discharging hydrogen and chloride ions. At the point when pepsinogen and 
hydrochloric acid exist together in the gastric juice, pepsin takes its dynamic structure ${ }^{[9]}$. Gastric juice renders food particles dissolvable, begins digestion (particularly of proteins), and converts the gastric substance to a semi-liquid mass called chyme, as such setting it up for extra preparing in the small intestine.

As noted above, the stomach walls are protected from digestive juices by the membrane on the surface of the epithelial cells bordering the lumen of the stomach; this membrane has enormous lipoproteins, these lipoproteins are resistant to attack of acid. The gastric juice of certain warm blooded animals (e.g., calves) contains the compound rennin, which clusters milk proteins and consequently removes them from arrangement and makes them more vulnerable to the activity of a proteolytic enzymes.[10]

\begin{tabular}{|l|l|}
\hline Kukserapranidanamaharena & There is no under pressure on the stomach due to the food taken. \\
\hline $\begin{array}{l}\text { Hrdayasyanavarodhah } \\
\text { Parsvayora Vipațanam }\end{array}$ & $\begin{array}{l}\text { There is no obstruction to the proper functioning of the heat. } \\
\text { There should not be any pressure in the sides of the chest. }\end{array}$ \\
\hline Anati Gauravamudarasya & There should not be excessive heaviness in the abdomen. \\
\hline Prinanamindriyanam & There is proper nourishment of the senses. \\
\hline Ksutpipasoparamah & There is relief from hunger and thirst. \\
\hline $\begin{array}{l}\text { Sthanasanasayanagamanocchvasa } \\
\text { Prasvasahasyasankathasu }\end{array}$ & $\begin{array}{l}\text { There is the feeling of comfort in standing, sitting, sleeping, walking, } \\
\text { exhaling, inhaling, laughing and talking. }\end{array}$ \\
\hline $\begin{array}{l}\text { Sayam Pratasca Sukhena } \\
\text { Parinamanam }\end{array}$ & $\begin{array}{l}\text { Food taken in the morning should get digested by the evening and the } \\
\text { food taken during the evening should get digested by the next morning. }\end{array}$ \\
\hline Balavarnopacayakaratvam Ca & There is promotion of strength, complexion and plumpness. \\
\hline
\end{tabular}

\section{Improper quantity of food is again of $\mathbf{2}$ types-deficient in quantity and excessive in quantity}

\begin{tabular}{|c|c|}
\hline Bala Varṇopacaya Kșayakaram Atrptikaram & Impairment of the strength, complexion and plumpness \\
\hline Udavartakaram & $\begin{array}{l}\text { Distension and absence of downward movement of food } \\
\text { in stomach and intestines }\end{array}$ \\
\hline Anayusya Vrșyamanaujasyam & Impairment of longevity, virility and Ojas \\
\hline Sarira Mano Buddhindriyopaghatakaram & Affliction of body, mind, intellect and senses \\
\hline Sara Vidhamanamalakșmyavahamasitesca & Impairment of excellence of Dhatus \\
\hline Vatavikaraṇamayatanamacakșate & Causation of eighty varieties of Vatika diseases. \\
\hline
\end{tabular}

Food taken in over the top amount irritates all the 3 Doshas. One who tops off his stomach with strong food and afterward takes fluid food in exorbitant amount, all the 3 Doshas, viz. Vata (Samana Vayu), Pitta and Kapha living in the stomach get an excessive amount of compacted and all the while disturbed. The irritated Doshas influence the undigested food and get stirred up with it. Then, at that point they hinder a piece of the stomach and immediately travel through vertical and descending plots independently to create the accompanying sicknesses in the individual, taking food in overabundance:

\section{Table 3: excess in quantity will produce the following symptoms:[3]}

\section{Vata produces}

Shula- Colic pain

Aanaha - Constipation

Anga marda- Malaise

Mukhasosa- Dryness of mouth

Bhrama- Fainting

Agnivaisamya -Irregularity in the power of

digestion,

Parsva prsța kațigraha - Rigidity of sides,

back and waist

Sirakuncana stambhanani karoti-

Contraction and hardening of vessels

\begin{tabular}{|l|l|}
\hline Pitta produces & Kapha produces \\
\hline Jwara- Fever & Chardi - Vomiting \\
Atisara- Diarrhea & arochaka -Anorexia \\
Antar daha- Burning & Avipaka - Indigestion \\
sensation in body & Shita jvara - Cold fever \\
Trushna -Thirst & Aalasya - Laziness and \\
Mada- Intoxication & Gatra gaurava - \\
Bhrama - Fainting & Heaviness in the body. \\
Pralap - Delirium & \\
& \\
& \\
\end{tabular}


The words 'indigestion' and 'dyspepsia' suggest some disturbance in the chemical process that food material undergo in the gastrointestinal tract. Indigestion often associated with other symptoms like epigastric discomfort or pain, frequently related to meals, anorexia, gaseous eructation, regurgitation, nausea and vomiting and sometime headache, palpitations and general nervousness and weakness. Indigestion caused due to disturbed gastric physiology or dysfunction of stomach or a disturbance of motor function of stomach and rarely due to the secretory function.

Distress or pain in the epigastrium is believed to be due to an increase in the tension of the stomach walls, which often occurs due to overeating that may be incident to spasm, especially of cardiac, pylorus or proximal duodenum to increased tone of its general musculature, to overfilling of organ or to variation in normal progression of its peristaltic waves. Eructation, regurgitation, nausea and vomiting even anorexia are also some kind, at time to an actual reversal of the peristaltic wave. Thus though indigestion may have many varied causes it apparently always in itself represents a localized motor disturbance of stomach[11].

While describing Matra of food to be taken, Acharya Sushruta has preached that food which are difficult for digestion should be consumed to half of one's capacity of digestion while food which are easy for digestion, should be consumed to one's satisfaction (contentment); food which have more of fluid or fluid itself, there is no difficulty regarding their quantity that is to be consumed. Those foods which are dry, when consumed with more fluid get digested properly. When Pitta aggravating food is consumed or food stays for a long time in the alimentary tract or when food causing heartburn is consumed, in such condition the food does not undergo digestion properly. Food which are dry, incompatible, and causing constipation will bring about abnormalities of the digestive fire ${ }^{[12]}$.

\section{CONCLUSION}

As per Acharya charaka diet ought to be taken by separating the stomach limit into 3 sections: One piece of it is topped off with solid food, the second part with fluids to make Kled in stomach which is fundamental for proper digestion and the third part is left for Vata, Pitta and Kapha. Vata for the movement of food, Pitta produces Ushma for digestion of food, Kapha structures Sneha because hard food can't digest as expected. One who takes food with due respect to this standard, doesn't fall a casualty to food with unsafe impacts which emerge out of food taken in illadvised amount.

\section{REFERENCES}

1. Acharya Agnivesha, Acharya Charaka, Acharya Dhridhabala, charaka Samhita of agnivesh volume 1, Sutra sthana, Annapanavidhim adhyaya, 27/3, Text with English Translation and Critical Exposition based on Cakrapani Dattas Ayurved Dipika by Dr. Ram Karan Sharma, Vaidya Bhagwan Dash published by choukhamba Sanskrit Series Office, Varanasi, reprint 2009, pg.no.490.)

2. Owens SR, Greenson JK. The pathology of malabsorption: current concepts. Histopathology. 2007; 50: 64-82.

3. Acharya Agnivesha, Acharya Charaka, Acharya Dhridhabala, charaka Samhita of agnivesh volume 1 , viman sthana, trividhkukshiya viman adhyaya, 2/3,6,7, Edited with Vaidyamanorama Hindi Commentary by Acharya Vidyadhar Shukla and prof. Ravi Datta Tripathi, forword by Acharya Priy Vrata Sharma, published by choukhamba Sanskrit Pratishthan, Delhi, reprint 2017, pg.no.561-562.

4. Derakhshan AR, Yousefi M, Dehghan S, Zargaran A, Khodadoost M. Digestion process and causes of indigestion based on Avicenna's view and modern medicine. Tradit Med Res. 2019; 4(3): 140-7.

5. Acharya Agnivesha, Acharya Charaka, Acharya Dhridhabala, Charaka Samhita of Agnivesh volume 1, Sharir sthana, Sharir vichay sharir adhyaya, 6/14,15, Edited with Vaidyamanorama Hindi Commentary by Acharya Vidyadhar Shukla and prof. Ravi Datta Tripathi, forward by Acharya Priy Vrata Sharma, published by Choukhamba Sanskrit Pratishthan, Delhi, reprint 2013, pg.no.755.

6. Make Takata, Studies In The Gastric Juice. III. On the empty stomach juice, the secretion at the time when the stomach is empty, The Journal of biochemistry, 1922,Online ISSN :1756-2651 Print ISSN : 0021-924X page no. 107-121

7. Klok MD et al. The role of leptin and ghrelin in the regulation of food intake and body weight in humans: a review. Obesity Reviews. 2007;8(1):2134. https://badgut.org/information-centre/a-zdigestive-topics/hunger-and-appetite/

8. Muhammad Wasim, Review article open access Role of leptin in obesity, Journal of Obesity \& Weight Loss Therapy April 30,2015, vol-5, issue-2, 1000258, pg.no.1,2, J Obese Weight Loss Ther 5:258. DOI:10.4172/2165-7904.1000258.

9. Heda R, Toro F, Tombazzi CR. Physiology, Pepsin., In: Stat Pearls [Internet]. Treasure Island (FL): StatPearls Publishing; 2021 Jan-. Available from: https://www.ncbi.nlm.nih.gov/books/NBK537005

10. Hightower, Nicholas Carr, Dworken, Harvey J., Sircus, William and Keeton, William T. "Human digestive system". Encyclopedia Britannica, 4 Nov. 2020, 
https://www.britannica.com/science/human-

digestive-system. Accessed 15 September 2021. https://www.britannica.com/science/human-

digestive-system/Gastric-secretion

11. T. Grier Miller, The causes of Indigestion and Their Recognition, The New England Journal Of Medicine, March 27, 1941, N Engl J Med 1941; 224; 537-540,
DOI:10.1056/NEJM194103272241302, Vol 224 No.13 p.g. no. 537.

12. K.R. Srikantha Murthy, Susruta Samhita with English translation, vol.1, Sutra Sthana Chapter 64, Verse 495, 497, 498 page No. 450 Chaukhamba orientalia, reprint 2010.

\section{Cite this article as:}

Manjiri Palnitakar Bhende, Prachi Dwarkaprasad Walde. Importance of Trividh Kukshiya Matravat Aahara in Relation to Digestion of the Food. International Journal of Ayurveda and Pharma Research. 2021;9(9):64-68.

https://doi.org/10.47070/ijapr.v9i9.2029

*Address for correspondence Dr. Prachi Dwarkaprasad Walde PG Scholar,

Department of Swasthavritta and Yoga, R. A. Podar Medical (Ayu) College Worli, Mumbai.

Mob: 9373692589

Email: prachiwalde93@gmail.com

Disclaimer: IJAPR is solely owned by Mahadev Publications - dedicated to publish quality research, while every effort has been taken to verify the accuracy of the content published in our Journal. IJAPR cannot accept any responsibility or liability for the articles content which are published. The views expressed in articles by our contributing authors are not necessarily those of IJAPR editor or editorial board members. 